\title{
Pengaruh Latihan Groundstroke Dengan Menggunakan Sasaran Terhadap Kemampuan Groundstroke Tenis Lapangan
}

\author{
Vrima Arga Nababan, Albadi Sinulingga \\ Fakultas Ilmu Keolahragaan, Universitas Negeri Medan \\ vrimaarga04@gmail.com, badisling@hotmail.com
}

\begin{abstract}
Abstrak: Penelitian ini bertujuan untuk mengetahui pengaruh latihan groundstroke dengan menggunakan sasaran terhadap kemampuan groundstroke. Sampel yang digunakan dalam penelitian ini adalah atlet putra Komunitas Tenis Unimed yang berjumlah 7 orang yang diambil secara purposive sampling. Metode penelitian ini adalah metode eksperimen dengan rancangan penelitian Pretest Posttest Group dengan latihan menggunakan sasaran yang dilaksanakan selama 6 minggu. Instrumen tes yang digunakan adalah Hewwit Tennis Test. Teknik analisis data yang digunakan adalah uji normalitas lilifors, uji homogenitas dan uji hipotesis yaitu uji-t dengan taraf signifikan 0,05 . Hasil yang diperoleh dari uji hipotesis yaitu pada kemampuan groundstroke forehand diperoleh thitung $(4,4152)>t_{\text {tabel }}(2,44691)$, sedangkan pada kemampuan groundstroke backhand diperoleh $t_{\text {hitung }}$ $(4,1030)>t_{t a b e l}(2,44691)$. Berdasarkan kriteria pengujian hipotesis, maka $\mathrm{H}_{\mathrm{a}}$ diterima dan $\mathrm{H}_{\mathrm{o}}$ ditolak sehingga dapat disimpulkan bahwa terdapat pengaruh latihan dengan menggunakan sasaran terhadap kemampuan groundstroke.
\end{abstract}

Kata Kunci : Kemampuan Groundstroke, Sasaran, Tenis Lapangan

\section{The Effect of Groundstroke Training Using Targets on The Groundstroke Ability of Tennis}

\begin{abstract}
The research aims to determine the effect of groundstroke training using targets on groundstroke ability of the Unimed Tennis Community 2020. The sample that used was 7 male athletes who were taken by purposive sampling. The methods used in this research was experiment method with the research design was pretest -posttest group with the using training of target was held for sixteen weeks. The test instrument used was Hewwit Tennis Test. The data analysis technique was Lilifors normality test, homogeneity test, and hyphotesis test was t-test with a sifnificiant level of 0,05. The result of hyphotesis test of the groundstroke forehand ability obtained $t_{\text {score }}(4,4152)>t_{\text {standart }}$ $(2,44691)$, while the groundstroke backhad ability obtained $t_{\text {score }}(4,1030)>t_{\text {standart }}(2,44691)$. Based on the hyphotesis test criteria, Ha was accepted and Ho was rejected, so the it can be included that there was an effect of groundstroke training using targets on groundstroke ability.
\end{abstract}

Keywords: Groundstroke Ability, Targets, Tennis

\section{PENDAHULUAN}

Olahraga merupakan salah satu cara untuk mengembangkan dan meningkatkan kesehatan jasmani dan rohani. Kegiatan olahraga mencakup berbagai macam cabang seperti atletik, permainan, olahraga air dan olahraga beladiri. Olahraga permainan salah satunya adalah olahraga tenis. Tenis adalah salah satu jenis olahraga populer dan banyak digemari semua lapisan masyarakat termasuk di Indonesia. Berkembangnya tenis disebabkan karena tenis merupakan salah satu cabang olahraga yang dapat dimainkan oleh semua orang, mulai dari anak-anak, orang dewasa, hingga orang tua. Tenis telah mencapai tahap perkembangan sangat pesat dan menarik perhatian sebagian orang.

Olahraga tenis lapangan mempunyai ciri khas tersendiri. Menurut Rolf Flichtbeil, (2006: 7) teknik pukulan dalam bermain tenis ada lima macam yaitu: groundstroke, service, volley, smash, lob. 
Olahraga tenis lapangan mempunyai laju bola yang sangat cepat dan alat pukul yang menggunakan senar yang disebut raket. Oleh karena itu, seorang atlet tenis lapangan harus memahami dengan benar mengenai kapan waktu yang tepat bagi seorang atlet untuk memukul bola yang datang dari arah lawan. Seorang atlet harus memperhitungkan kecepatan dan mengetahui arah putaran bola serta memperhitungkan arah putarannya. Beberapa hal tersebut di atas secara keseluruhan harus dapat dilakukan dalam waktu yang singkat. Keberhasilan dalam permainan tenis untuk seorang atlet harus melewati sepuluh komponen fisik menurut Harsono (2001: 58), yaitu: (1) kekuatan, (2) daya tahan, (3) power, (4) kecepatan, (5) kelentukan, (6) keseimbangan, (7) koordinasi, (8) kelincahan, (9) ketepatan/accuracy, (10) reaksi.

Groundstroke merupakan teknik yang paling penting dalam permainan tenis lapangan karena groundstroke merupakan pukulan yang paling sering digunakan, pukulan groundstroke juga menjadi salah satu senjata dalam memenangkan pertandingan. Dan pukulan ini sering dijadikan pukulan untuk menyerang. Bagi pemain pemula, salah satu jenis pukulan yang harus dikuasai adalah groundstroke. Hal ini dikarenakan, groundstroke yang sangat penting yang harus dikuasai oleh pemain, sebab dalam melakukan permainan atau pertandingan groundstroke merupakan yang paling banyak dilakukan. seperti yang dikemukakan oleh Kriese (1988) bahwa "rata-rata pemain melakukan groundstroke dalam permainan $35-45 \%$ dari keseluruhan pukulan selama permainan atau pertandingan".

Menurut Irawadi (2016) groundstroke adalah "Pukulan yang dilakukan setelah bola memantul di lapangan permainan". Begitu juga dengan Brown (2007) mengatakan groundstroke adalah "pukulan yang dilakukan baik dengan forehand atau backhand setelah memantul di lapangan". Palmizal (2011) juga mengatakan bahwa groundstroke diartikan sebagai memukul bola setelah memantul dilantai atau lapangan. Irawadi (2016) menjelaskan bahwa menurut pelaksanaanya, groundstroke terbagi 2 yaitu: forehand dan backhand. Forehand adalah salah satu jenis pukulan dalam permainan tenis yang dipukul setelah bola memantul terlebih dulu dilapangan, dan dipukul dari arah sebelah kanan dari yang memegang raket dengan tangan kanan, dan dari sebelah kiri dari bagi yang memegang raket dengan tangan kiri. Dan groundstroke backhand adalah salah satu jenis pukulan dalam permainan tenis yang dipukul setelah bola memantul terlebih dulu di lapangan dan dipukul dari arah sebelah kiri bagi yang memegang raket dengan tangan kanan, dan dari sebelah kanan bagi yang memegang raket dengan tangan kiri.

Komunitas Tenis Unimed adalah salah satu klub tenis di Medan yang menampung minat dan bakat mahasiswa dalam bermain tenis. Adapun anggota dari komunitas ini adalah mahasiswa Unimed yang mengikuti latihan pada sore hari. Peneliti telah melakukan beberapa kali pengamatan dan observasi di komunitas ini pada saat melakukan coaching clinic. Pada saat melakukan coaching clinic, peneliti di berikan tugas melatih atlet dan membuat program latihan, di saat peneliti memberikan bentuk latihan dril menggunakan bola, peneliti mengamati groundstroke atlet di saat latihan. Dari hasil pengamatan peneliti melihat groundstroke atlet Komunitas Tenis Unimed rendah dan untuk meyakinkan peneliti juga melakukan tes groundstroke yang diukur dengan menggunakan instrumen hewitt tennis achievement test. Dalam tes dan pengukuran yang dilakukan terhadap atlet putra Komunitas Tenis Unimed yang bertujuan untuk mengukur kemampuan groundstroke atlet putra Komunitas Tenis Unimed, disimpulkan bahwa kemampuan groundstroke atlet putra Komunitas Tenis Unimed masih rendah berdasarkan normal skala penilaian hewitt tennis achievement test.

Dari hasil tes pengukuran yang dilakukan maka ditemukan kemampuan groundstroke anggota Komunitas Tenis Unimed masih rendah sehingga perlu untuk dikaji hal-hal yang dapat meningkatkan kemampuan tersebut mengingat begitu pentingnya kemampuan groundstroke yang baik dalam bermain tenis. Latihan groundstroke merupakan bentuk latihan yang memadukan ketepatan dan arah bola pada pemain tenis. Namun, masih ditemukan beberapa kesalahan sehingga pukulan hanya monoton dan tidak ada variasi pukulan. Padahal, variasi pukulan sangat penting dalam permainan tenis lapangan, karena dengan adanya variasi pukulan akan memudahkan pemain tenis dalam mengatur tempo serta arah bola. Peneliti tertarik untuk melakukan eksperimen dengan menggunakan media sasaran yang telah dikembangkan oleh Jonathan C. Samosir (2019) untuk mengetahui pengaruh latihan dengan media sasaran terhadap kemampuan groundstroke. Latihan groundstroke menggunakan media sasaran adalah salah satu bentuk latihan yang dapat meningkatkan kemampuan tenis lapangan dan juga dapat memperbaiki teknik pukulan serta berfungsi untuk memudahkan pemain mengarahkan bola. Berdasarkan permasalahan di atas dapat diketahui bahwa kemampuan groundstroke Komunitas 
Tenis Unimed masih rendah. Oleh karena itu, peneliti akan mencoba menyusun sebuah penelitian yang fokus pada upaya untuk meningkatkan kualitas groundstroke melalui pemberian model latihan.

\section{METODE}

Penelitian ini akan dilakukan di lapangan tenis Universitas Negeri Medan yang dilaksanakan selama 6 minggu dengan 3 kali latihan dalam satu minggu. Adapun perlakuan dilakukan pada sore hari di lapangan tenis terbuka. Dalam penelitian ini yang menjadi populasi adalah seluruh anggota Komunitas Tenis Universitas Negeri Medan yang berjumlah 15 orang. Teknik pengambilan sampel yang digunakan dalam penelitian ini adalah teknik purposive sampling yang terdiri dari 7 atlet putra, yaitu dengan pertimbangan yang dilakukan peneliti memiliki ketentuan pengambilan sampel dengan memberikan kriteria antara lain: (1) Pemain tenis putra, (2) Telah menguasai pukulan groundstroke, (3) Aktif dalam mengikuti latihan, (4) Terdaftar dalam Komunitas Tenis Unimed, (5) Berbadan sehat, (6) Bersedia menjadi sampel peneliti. Metode penelitian yang digunakan dalam penelitian ini adalah quasi experiment atau disebut juga eksperimen semu dengan menggunakan rancangan pre-test dan post-test group. Instrumen penelitian mencakup segala sesuatu yang digunakan dalam penelitian yakni hewitt tennis achievement test. Faktor penting dalam penelitian yang berhubungan dalam data adalah metode pengumpulan data. Arikunto dan Jabar (2004) menyatakan pengertian pengukuran (measurement) sebagai kegiatan membandingkan suatu hal dengan satuan ukuran tertentu sehingga sifatnya menjadi kuantitatif. Adapun teknik analisis data yang digunakan adalah uji normalitas dan uji homogenitas. Uji hipotesis yang digunakan adalah uji-t. Hal itu sejalan dengan pendapat dari (Sudjana, 2009) yang mengatakan bahwa penelitian kuantitatif dapat dianalisis dengan menggunakan uji $t$.

\section{HASIL DAN PEMBAHASAN}

\section{Data Pretest dan Posttest Kemampuan Groundstroke}

Berdasarkan data pretest dan posttest kemampuan groundstroke yang diperoleh pada penelitian ini dan setelah data ditabulasikan maka diperoleh rata-rata pretest dan posttest groundstroke forehand dan backhand dimana rata-rata kemampuan forehand groundstroke pada pretest adalah 16 sedangkan pada backhand groundstroke adalah 16,28. Rata rata pada forehand groundstroke adalah 24,14 dan groundstroke backhand adalah 21,14. seperti pada tabel dibawah ini:

Tabel 1. Rata-Rata Pretest dan Posttest

\begin{tabular}{lcc}
\hline \multirow{2}{*}{ Groundstroke } & \multicolumn{2}{c}{ Rata-Rata } \\
\cline { 2 - 3 } & Pretest & Posttest \\
\hline Forehand & 16 & 24,1429 \\
\hline Backhand & 16,2857 & 21,1429 \\
\hline
\end{tabular}

\section{Distribusi Persentase Data Pretest dan Posttest Kemampuan Groundstroke}

\section{a. Pretest Groundstroke Forehand}

Data penelitian melalui tes pengukuran terhadap kemampuan groundstroke tennis dilakukan sebelum dan sesudah diberikan perlakuan. Data tersebut di deskripsikan dalam bentuk grafik.

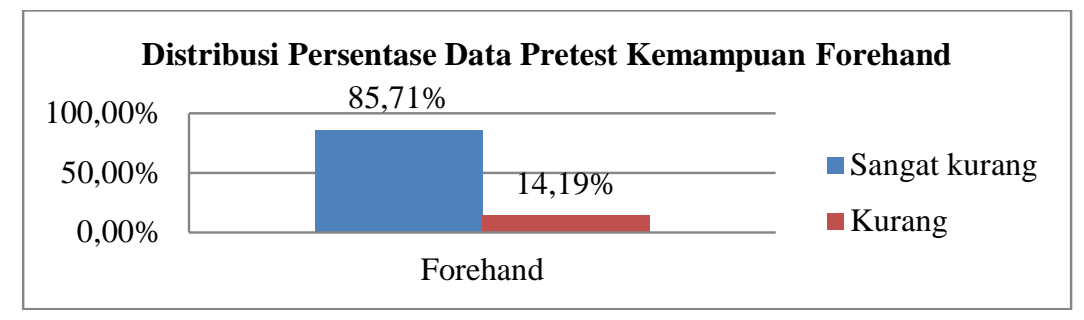

Gambar 1. Distribusi Persentase Data Pretest Kemampuan Forehand 
Adapun deskripsi data tersebut distribusi frekuensi pretest forehand groundstroke dengan jumlah sampel sebanyak 6 pemain tennis adalah 85,71\% dalam kategori sangat kurang dan 1 pemain tennis $14,29 \%$ dengan kategori buruk.

\section{b. Pretest Groundstroke Backhand}

Hasil penelitian distribusi frekuensi prestest backhand 6 orang $(85,71 \%)$ dengan kategori sangat kurang dan 1 orang $(14,29 \%)$ dengan kategori buruk.

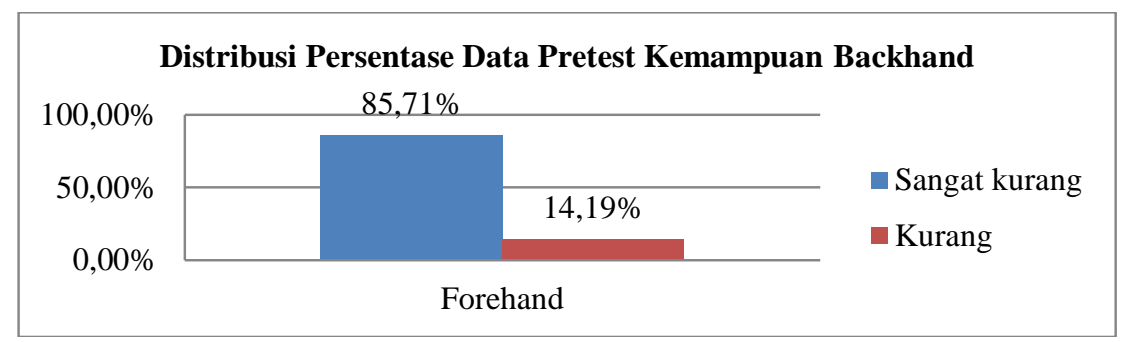

Gambar 2. Distribusi Persentase Data Pretest Kemampuan Backhand

\section{c. Posttest Groundstroke Forehand}

Hasil penelitian distribusi frekuensi posttest forehand 4 orang $(57,14 \%)$ dengan kategori sangat kurang, 2 orang $(28,57 \%)$ dengan kategori kurang dan 1 orang $(14,29 \%)$ dengan kategori cukup.

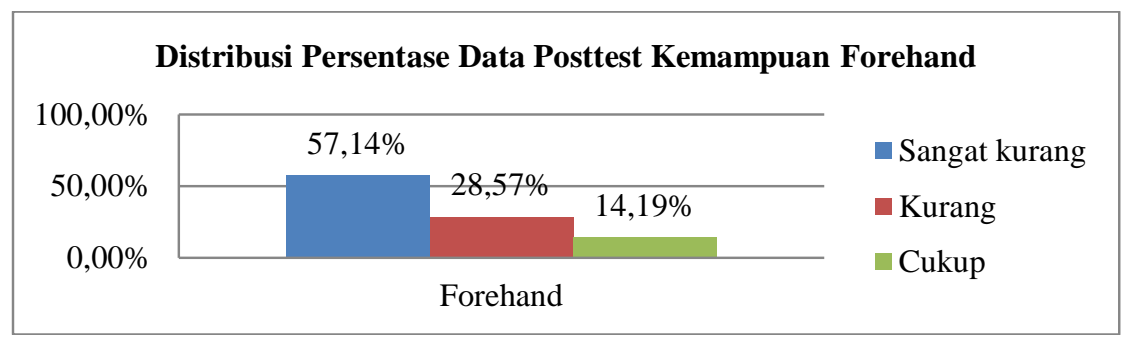

Gambar 3. Distribusi Persentase Data Posttest Kemampuan Forehand

\section{d. Posttest Groundstroke Backhand}

Hasil penelitian distribusi frekuensi posttest backhand 6 orang $(85,71 \%)$ dengan kategori sangat kurang dan 1 orang $(14,29 \%)$ dengan kategori kurang.

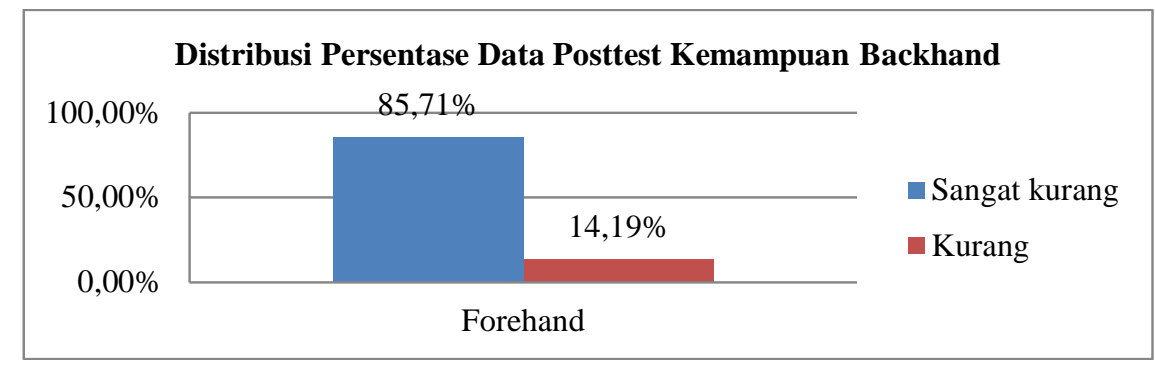

Gambar 4. Distribusi Persentase Data Posttest Kemampuan Backhand 


\section{Uji Normalitas}

Uji ini dilakukan untuk mengetahui apakah data yang digunakan berdistribusi normal atau tidak. Hasil perhitungan untuk uji normalitas data pretest dan posttest kemampuan groundstroke dapat dilihat pada tabel sebagai berikut :

Tabel 2. Hasil Uji Normalitas Pretest dan Posttest pada Groundstroke Forehand

\begin{tabular}{cccccc}
\hline Forehand & Lo & $\mathbf{L}_{\text {tabel }}$ & $\boldsymbol{\alpha}$ & $\mathbf{N}$ & Ket \\
\hline Pretest & 0,1931 & 0,300 & 0,05 & 7 & Normal \\
\hline Posttest & 0,1318 & 0,300 & 0,05 & 7 & Normal \\
\hline
\end{tabular}

Hasil uji normalitas pada data pre tes kemampuan groundstroke forehand dari 7 orang sampel penelitian menujukkan bahwa Lo < Lt $(0,1931<0,300)$ sehingga dapat disimpulkan data pre test kemampuan groundstroke forehand adalah normal. Sedangkan data post test kemampuan groundstroke forehand diperoleh Lo $<\mathrm{Lt}(0,1318<0,300)$ sehingga dapat disimpulkan data post test kemampuan groundstroke forehand adalah normal.

Tabel 3. Hasil Uji Normalitas Pretest dan Posttest pada Groundstroke Backhand

\begin{tabular}{cccccc}
\hline Forehand & Lo & $\mathbf{L}_{\text {tabel }}$ & $\boldsymbol{\alpha}$ & $\mathbf{N}$ & Ket \\
\hline Pretest & 0,2082 & 0,300 & 0,05 & 7 & Normal \\
\hline Posttest & 0,1117 & 0,300 & 0,05 & 7 & Normal \\
\hline
\end{tabular}

Hasil uji normalitas pada data pre tes kemampuan groundstroke backhand dari 7 orang sampel penelitian menujukkan bahwa Lo < Lt $(0,2082<0,300)$ sehingga dapat disimpulkan data pre test kemampuan groundstroke backhand adalah normal. Sedangkan data post test kemampuan groundstroke backhand diperoleh Lo $<\mathrm{Lt}(0,1117<0,300)$ sehingga dapat disimpulkan data post test kemampuan groundstroke backhand adalah normal.

\section{Uji Homogenitas}

Uji ini dilakukan untuk mengetahui apakah kedua varian sampel homogen. Data homogen apabila harga $F_{\text {hitung }}<F_{\text {tabel, }}$, pada taraf signifikan 5\% $(\alpha=0,05)$. Hasil perhitungan uji homogenitas ini dapat dilihat pada tabel dibawah :

\section{a. Forehand}

Tabel 4. Hasil Uji Normalitas Kemampuan Forehand

\begin{tabular}{cccccc}
\hline Forehand & $\mathbf{F}_{\text {hitung }}$ & $\mathbf{F}_{\text {tabel }}$ & $\boldsymbol{\alpha}$ & $\mathrm{dk}(\mathbf{n}-\mathbf{1})$ & Ket \\
\hline Varians Pretest dan Posttest & 1,55633 & 4,28 & 0,05 & 6 & Homogen \\
\hline
\end{tabular}

Dari hasil analisis uji homogenitas pada kemampuan groundstroke forehand diperoleh $\mathrm{F}_{\text {hitung }}<$ $\mathrm{L}_{\text {tabel }}(1,556<4,28)$ dengan $\mathrm{dk} \mathrm{n}-1=6$ sehingga dapat disimpulkan data pre test kemampuan groundstroke forehand adalah homogen. 


\section{b. Backhand}

Tabel 5. Hasil Uji Normalitas Kemampuan Backhand

\begin{tabular}{cccccc}
\hline Backhand & F $_{\text {hitung }}$ & F $_{\text {tabel }}$ & $\boldsymbol{\alpha}$ & Dk (n - 1 ) & Ket \\
\hline Varians Pretest dan Posttest & 1,10912 & 4,28 & 0,05 & 6 & Homogen \\
\hline
\end{tabular}

Dari hasil analisis uji homogenitas kemampuan groundstroke backhand adalah diperoleh $\mathrm{F}_{\text {hitung }}$ $<\mathrm{L}_{\text {tabel }}(1,556<4,28)$ dengan $\mathrm{dk} \mathrm{n}-1=6$ sehingga dapat disimpulkan data pre test kemampuan groundstroke backhand adalah homogen.

\section{Uji Hipotesis}

Uji ini dilakukan untuk mengetahui apakah kesimpulan awal dari kajian teori yang dilakukan atau hipotesis diterima atau ditolak. Data hasil uji hipotesis Uji-t dapat dilihat pada tabel dibawah ini :

\section{a. Forehand}

Dari hasil pengujian hipotesis terhadap kemampan groundstroke forehand diperoleh $\mathrm{t}_{\text {hitung }} 4,415$ dan $t_{\text {tabel }}$ dengan $\mathrm{dk}=(\mathrm{n}-1)=6$ pada taraf nyata $0,05(\alpha=5 \%)$ maka harga $\mathrm{t}_{\text {tabel }}=2,44691$, maka dapat dinyatakan bahwa $t_{\text {hitung }}>t_{\text {tabel }}=4,415>2,447$. Dari hasil analisis tersebut dapat disimpulkan bahwa latihan groundstroke menggunakan media sasaran dapat meningkatkan kemampan groundstroke forehand. Adapun hasil analisis di simpulkan pada tabel di bawah ini :

Tabel 6. Hasil Uji Hipotesis $(\mathrm{Uji}-\mathrm{t})$ Kemampuan Forehand

\begin{tabular}{cccccc}
\hline & \multicolumn{2}{c}{ Data } & $\mathbf{t}_{\text {hitung }}$ & $\mathbf{t}_{\text {tabel }}$ & Ket \\
\cline { 2 - 3 } & Pretest & Posttest & & & \\
\hline$\sum X$ & 112 & 169 & & & \\
\hline $\bar{X}$ & 16 & 24,1429 & & & \\
\hline $\mathbf{S}$ & 6,40312 & 7,98809 & 415 & 2,447 & Ha diterima \\
\hline $\mathbf{N}$ & 6 & 6 & & & Ho Ditolak \\
\hline
\end{tabular}

\section{b. Backhand}

Dari hasil pengujian hipotesis terhadap kemampan groundstroke backhand diperoleh $\mathrm{t}_{\text {hitung }} 4,103$ dan $t_{\text {tabel }}$ dengan $\mathrm{dk}=(\mathrm{n}-1)=6$ pada taraf nyata $0,05(\alpha=5 \%)$ maka harga $\mathrm{t}_{\text {tabel }}=2,447$, maka dapat dinyatakan bahwa $t_{\text {hitung }}>t_{\text {tabel }}=4,103>2,447$. Dari hasil analisis tersebut dapat disimpulkan bahwa latihan groundstroke menggunakan media sasaran dapat meningkatkan kemampan groundstroke backhand.

Tabel 7. Hasil Uji Hipotesis $(U j i-t)$ Kemampuan Backhand

\begin{tabular}{cccccc}
\hline & \multicolumn{2}{c}{ Data } & $\mathbf{t}_{\text {hitung }}$ & $\mathbf{t}_{\text {tabel }}$ & Ket \\
\cline { 2 - 3 } & Pretest & Posttest & & & \\
\hline$\sum X$ & 114 & 148 & & & \\
\hline $\bar{X}$ & 16,2857 & 21,1429 & & & \\
\hline $\mathbf{S}$ & 6,1837 & 5,87164 & & & \\
\hline $\mathbf{N}$ & 6 & 6 & & & \\
\hline
\end{tabular}

Dari hasil pengujian hipotesis tersebu dapat disimpulkan bahwa terdapat pengaruh yang signifikan dari latihan groundstroke menggunakan sasaran terhadap kemampuan groundstroke. Latihan groundstroke menggunakan sasaran merupakan latihan yang membangun kemampuan pemain tennis dalam mempersepsikan arah dan target sasaran pukulan. Dengan kemampuan pemain tenis dalam mempersepsikan arah dan target yang tepat maka permainan akan dapat dikendalikan sehingga dapat memenangkan pertandingan. Pemain tennis yang tidak dapat mengatur jarak dan arah 
pukulannya maka cenderung pukulan tidak memiliki arah dan hanya akan kembali begitu saja. Dengan demikian lawan akan mudah untuk mengembalikan bola sehingga pertandingan akan dikendalikan oleh lawan. Perlu kirannya pemain menguasai kemampuan untuk mengarahkan pukulan groundstrokenya baik itu forehand maupun backhand sehingga tidak ada kelemahan yang akan digunakan oleh lawan untuk menyerang dan menghasilkan point.

\section{SIMPULAN}

Berdasarkan hasil penelitian yang telah diperoleh melalui uji hipotesis, maka dapat disimpulkan bahwa terdapat pengaruh latihan groundstroke dengan menggunakan sasaran terhadap kemampuan groundstroke. Perlu kiranya pelatih dan juga pemain tennis agar memberikan latihan dengan menggunakan sasaran pada saat melatih kemampuan groundstroke baik forehand maupun backhand. Kemamuan mengarahkan bola ke sasaran menjadi hal dasar yang harus dimiliki oleh setiap pemain tennis untuk melakukan serangan terhadap pertahanan lawan sehingga dapat menghasilkan point demi point dan pada akhirnya akan memenangkan pertandingan.

\section{DAFTAR PUSTAKA}

A, Palmizal. (2011). Pengaruh Metode Latihan Global Terhadap Akurasi Ground Stroke Forehand Dalam Permainan Tenis [Online]. download.portalgaruda.org

Arikunto, S. dan Jabar. (2004). Evaluasi Program Pendidikan. Jakarta: Bumi Aksara

Brown, J. (2007). Tenis Tingkat Pemula. Jakarta: PT. Raja Grafindo Persada.

Harsono (2001), Latihan Kondisi Fisik, FPOK UPI; Bandung

Irawadi, H. (2016). Cara Mudah Menguasai Tenis. Padang : Wineka Media Malang.

Jonathan C. Samosir (2019). Pengembangan Media Sasaran Terhadap Kemampuan Bermain Tennis. Skripsi FIK-Unimed.

Kriese, Chuck. (1988). Total Tennis Training: Realizing Your Physical, Mental, and Emotional Potential. Michigan, USA: Masters Press.

Rolf Flichtbeil, (2006), Go Tennis, Great Britain: Dorling Kindersley Limited.

Sajoto M. (1988). Pembinaan Kondisi Fisik Dalam Olahraga. Jakarta : Depdikbud

Sudjana, (2009). Metode Statistika, Bandung: Penerbit Tarsito. 